\title{
Getting Engaged in America
}

\section{1- Introduction}

The National Curricular Parameters of 2000 point out a new path for the teaching of foreign languages in Brazilian school. They determine that the language must be taught in such a way that it enables students to actually communicate by using the language. They also suggest that the teaching of a foreign language should allow students to learn about foreign cultures as well. The National Curricular Parameters (2000:25) state that, "the Foreign Languages take on the condition of being an indissoluble part of the set of essential knowledge that allow the student to approach several cultures and, consequently, promote his integration in a globalized world". Furthermore, the National Curricular Parameters assert that grammar must be taught in context and not isolated as it used to be.

Thus, this lesson plan has as its theoretical support those two ideas of the National Curricular Parameters: enabling students to learn about foreign cultures and teaching, or in the case of this plan in specific, reviewing a grammar topic in a real context of use.

\section{2- $\quad$ Target Audience}

Students of second year of High School.

\section{3- $\quad$ Teaching Situation}

Grammar review of Simple Past Tense

\section{4- Material}

DVD with the $25^{\text {th }}$ episode of the $6^{\text {th }}$ season of the sitcom Friends, named The one with the proposal-Part Two

\section{5- Objectives}

\subsection{General Objective}

The students should be able understand about the tradition of engagements in America.

\subsection{Specific Objectives}

By the end of the class it is expected that the students:

- $\quad$ develop their listening skills;

- $\quad$ improve their writing skills;

- $\quad$ practice their speaking skills;

- $\quad$ review the usage of Simple Past Tense 


\section{6- $\quad$ Time}

Two-hour class

\section{7- $\quad$ Class development}

\subsection{Warm up}

The teacher starts the class by inquiring students about their dreams for the future and what they expect their lives to be by the time they are thirty years old. Probably some will mention the dream of getting married and having a family. Then, they teacher will what they know about the tradition of getting engaged in America.

\subsection{Step one}

The teacher will tell students they are going to watch an episode of a sitcom called Friends, whose title is The one with the proposal. Then, she will hand out the activity (in annex) and read with them in order to check their comprehension and clarify what are the aspects of the video they must pay closer attention to.

\subsection{Step two}

Students watch the video once, with subtitles in English, to get to know what the episode is about.

\subsection{Step three}

The activity number 3 of their activity sheet is a listening activity. The teacher will play the scene of the activity again, only the specific scene, this time with no subtitles and will ask the students to fill in the blanks of the dialogue with the missing words, which are mostly verbs in the Simple Past Tense. The correction of this activity will be performed by the students themselves: the teacher will play the scene one more time, with English subtitles again, so students can check their answers. At this point, the teacher will make comments about the form of the verbs in the Simple Past and ask for their form in the Infinitive Form.

\subsection{Step five}

Students will do the other exercises in their activity sheet in pairs. The teacher will correct with the whole class, by asking each student to read one of the exercises.

\subsection{Step six}

In pairs, students will write a dialogue containing two characters: a couple. They are supposed to create a scene in which one member of the couple proposes to the other in an unusual way. After the teacher correction, students will perform their dialogue to the whole class.

\section{Wrap up:}


The students will evaluate their performances by talking about what was good and what could be improved.

\section{Annex: Activity Sheet}

\section{1- Match $T$ (true) of $F$ (false) according to the episode}

( ) Chandler really believed marriage was an unnatural thing.

( ) According to Chandler the divorce rate in the USA was 45 percent.

( ) Rachel was worried about not finding Love.

( ) Rachel was totally happy for Monica and Chandler.

( ) Phoebe had a deal with both Ross and Joey.

( ) Joey was dressed as a soldier because of his boat.

( ) Richard told Monica he wanted to marry her.

( ) Monica was still in Richard's apartment when Chandler arrived.

( ) Chandler told Monica he didn't want to marry her to do her a surprise.

\section{2- Choose the best alternative in each of the following:}

\section{I - Rachel and Phoebe's backup plan was:}

( ) To make a deal with a friend to get married with him by the time they were 40 .

( ) To have a partnership with a friend to guarantee financial support at their 40's.

( ) To meet as many guys as possible to not be single by their 40 's.

( ) To get married to any guy before their $40^{\text {th }}$ birthday.

\section{II - Monica told Richard that:}

( ) She never thought of him after they broke up.

( ) She thought of him once when she took an eye exam.

( ) She thought of him every night and day.

( ) She started thinking of him some days before.

\section{III- Phoebe was in doubt about picking Ross or Joey because:}

( ) Joey was handsome and Ross intelligent.

( ) Joey had a boat and Ross was a good father.

( ) Joey was kind and Ross rich.

( ) Joey was an actor and Ross a paleontologist.

IV - Monica told Chandler she was lucky because: 
( ) He wanted to marry her.

( ) She has two men who wanted to marry her.

( ) She had many nice friends.

( ) She fell in love with her best friend.

\section{V- When proposing, Chandler said that what mattered the most was:}

( ) Where and when he proposed.

( ) They continued being friends.

( ) The fact that she made him happier than he ever thought.

( ) They would marry and live in the same apartment.

\section{3 - Complete the dialogue between Chandler and Richard:}

C: Monica, Monica!

$\mathrm{R}: \mathrm{Ok}$, she here, but she

C: Where did she

$\mathrm{R}:$ She she to think things over...

C: My God, I can't this. I you a good guy.

R: Oh, good... Nothing

C: Nothing ? Nothing? So you my girlfriend that you her?

R: Ah, all right! One thing

C: I can't this. My girlfriend is out there thinking things over! You my girlfriend

R: Well, I'm sorry!

\section{4- Underline the verbs in the dialogue:}

a. Classify them into simple past or simple present.

b. Make a chart of the verbs with their infinitive and past forms.

c. Write a sentence for each verb, using the same context of the dialogue (two men talking about a girlfriend in a living room).

\section{References}


Parâmetros Curriculares Nacionais. Ensino Médio. Linguagens, códigos e suas tecnologias, 2000. Available at: http://portal.mec.gov.br/seb/arquivos/pdf/14_24.pdf. Accessed on June $7^{\text {th }}$, 2014.

FRIENDS: The one with the proposal. New York: Warner Bros, 2000. DVD. 